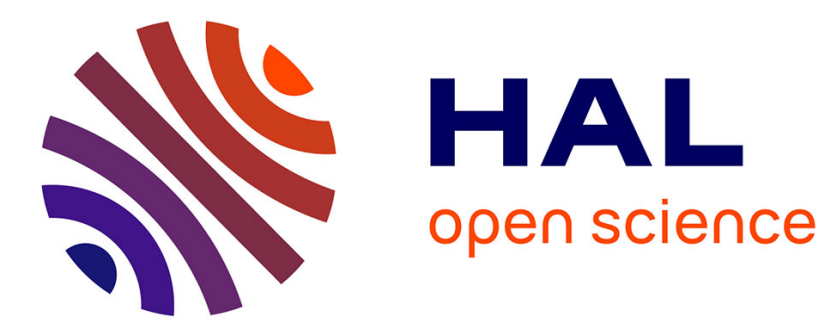

\title{
Ab-Initio Determination of La2Mo4O15 Crystal Structure from X-rays and Neutron Powder Diffraction
}

\author{
F. Dubois, F. Goutenoire, Y. Laligant, E. Suard, P. Lacorre
}

\section{To cite this version:}

F. Dubois, F. Goutenoire, Y. Laligant, E. Suard, P. Lacorre. Ab-Initio Determination of La2Mo4O15 Crystal Structure from X-rays and Neutron Powder Diffraction. Journal of Solid State Chemistry, 2001, 159 (1), pp.228-233. 10.1006/jssc.2001.9190 . hal-02194733

\section{HAL Id: hal-02194733 \\ https://hal.science/hal-02194733}

Submitted on 25 Jul 2019

HAL is a multi-disciplinary open access archive for the deposit and dissemination of scientific research documents, whether they are published or not. The documents may come from teaching and research institutions in France or abroad, or from public or private research centers.
L'archive ouverte pluridisciplinaire HAL, est destinée au dépôt et à la diffusion de documents scientifiques de niveau recherche, publiés ou non, émanant des établissements d'enseignement et de recherche français ou étrangers, des laboratoires publics ou privés. 


\title{
Ab-initio determination of $\mathrm{La}_{2} \mathrm{Mo}_{4} \mathrm{O}_{15}$ crystal structure from $\mathrm{X}$-rays and neutron powder diffraction
}

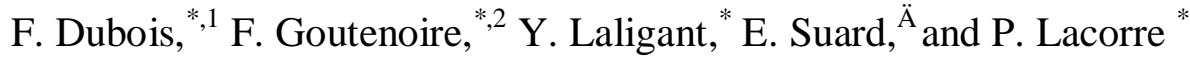 \\ * Laboratoire des Fluorures, UMR CNRS 6010, Université du Maine, 72085 Le Mans Cedex 9, France \\ ${ }^{\grave{A}}$ Institut Laue-Langevin, Avenue des Martyrs, B.P. 156, 38042 Grenoble Cedex 9, France
}

\begin{abstract}
The structure of $\mathrm{La}_{2} \mathrm{Mo}_{4} \mathrm{O}_{15}$ has been determined from both high resolution $\mathrm{X}$-ray and neutron powder diffraction data. This molybdate crystallizes in a monoclinic space group $P 2_{1} / n$ with cell parameters $a=9.0357(2) \AA, b=12.7737(2) \AA, c=10.6408(2) \AA, \beta=90.2491(6)^{\circ}$. The structure consists of molybdenum octahedra $\left[\mathrm{MoO}_{6}\right]$ and tetrahedra $\left[\mathrm{MoO}_{4}\right]$, and lanthanum polyhedra $\left[\mathrm{LaO}_{9}\right]$, Molybdenum polyhedra are connected together, forming large units $\left[\mathrm{Mo}_{6} \mathrm{O}_{22}\right]$, isolated by lanthanum polyhedral chains, This structure is compared with those of already known lanthanide molybdates with formula $L n_{2} \mathrm{Mo}_{4} \mathrm{O}_{15}$ $(L n=\mathrm{Ce}, \mathrm{Ho})$.
\end{abstract}

Keywords: lanthanum; molybdate; oxide; ab-initio structural determination; coupled refinement; X-rays and neutron powder diffraction

\section{INTRODUCTION}

The lanthanide molybdate compounds form a large family of materials with interesting physical properties. These properties depend on the crystal structures of these oxides and on the oxidation state of molybdenum. In the case of the molybdenum highest oxidation state, + VI, of interest here, one can mention for instance the ferroelectric/ferroelastic properties of $\mathrm{Gd}_{2} \mathrm{Mo}_{3} \mathrm{O}_{12}$ (1), the unusual negative thermal expansion of $L_{2} \mathrm{Mo}_{3} \mathrm{O}_{12}$ (2), the catalytic properties of $\mathrm{La}_{2} \mathrm{MoO}_{6}(3)$, and our recent discovery of fast oxideion conduction in $\mathrm{La}_{2} \mathrm{Mo}_{2} \mathrm{O}_{9}$ (4-6). This last finding incited us to reinvestigate the structure and properties of other compositions in the $\mathrm{La}^{\mathrm{III}}-\mathrm{Mo}^{\mathrm{VI}}-\mathrm{O}$ system. Among those, Alekseev et al. (7) pointed out the existence of an Mo-rich phase with composition $\mathrm{La}_{2} \mathrm{Mo}_{4} \mathrm{O}_{15}$, a tetragonal symmetry with cell paremeters: $a=15.85 \AA, c=9.595 \AA$, and up to now an unknown structure. In an attempt to prepare this phase, we obtained for this stoichiometry a compound with a different X-ray diagram and undertook a structural determination.

\section{EXPRIMENTAL}

\section{Synthesis}

The oxide $\mathrm{La}_{2} \mathrm{Mo}_{4} \mathrm{O}_{15}$ can be prepared from a mixture of $\mathrm{La}_{2} \mathrm{O}_{3}$ and $\mathrm{MoO}_{3}$ in the stoichiometric proportion 1:4. The

\footnotetext{
${ }^{1}$ Present address: Centre de Recherche sur la Matière Divisée, UMR CNRS-Université, 1 B Rue de la Férollerie 45071 Orléans Cedex 2, France.

${ }^{2}$ To whom correspondence should be addressed: Fax: 33.2.43.83.36.05. E-mail: francois.goutenoire@univ-lemans.fr.
}

weighted powder is mixed in an agate mortar, and then placed in an alumina crucible. This crucible is heated at $570-600^{\circ} \mathrm{C}$ for $12 \mathrm{~h}$. Attempts to increase the temperature of synthesis failed, the product being unstable above $650-675^{\circ} \mathrm{C}$. The final product is white.

\section{Structural Determination}

The electron diffraction study was performed on a 200-kV side-entry JEOL 2010 electron microscope with a doubletilt specimen holder operated at room temperature.

Powder diffraction patterns were collected on X-ray and neutron diffractometers (see Table 1). The X-ray pattern was recorded on a Bragg-Brentano diffractometer (Bruker D8) and the neutron pattern on a Debye-Scherrer diffractometer (D2b instrument at the ILL, Grenoble). No absorption correction was applied to the data. For the structural determination the atomic arrangement was found through direct method analysis and Fourier syntheses, using alternatively the programs FullProf (8), ShelxS86, and ShelxL93 (9).

\section{Crystal Symmetry}

Using the indexing program TREOR (10), we were not able to find an appropriate crystal cell. The electron diffraction patterns allowed us to evidence an orthorhombic type cell, with cell parameters $a \approx 9.0 \AA, b \approx 12.8 \AA, c \approx 10.7 \AA$. However, the splitting of some reflections in the high-resolution X-ray diffraction pattern could not be explained with 
TABLE 1

Condition of Acquisition of the Diffraction Patterns of $\mathrm{La}_{2} \mathrm{Mo}_{4} \mathrm{O}_{15}$ and Characteristics of the Refinement

\begin{tabular}{lcc}
\hline Diffractometer & Bruker-AXS D8 & D2B (ILL) \\
\hline Radiation & X-ray CuK $\alpha$ & Neutron $1.594365 \AA$ \\
$2 \theta$ Range $\left(^{\circ}\right)$ & $10-120$ & $0-160$ \\
Step-scan & $0.01^{\circ}$ & $0.05^{\circ}$ \\
Counting time & $40 \mathrm{~s}$ & $2 \mathrm{~h}($ total) \\
$R_{\text {BRAGG }}(\%)$ & 2.8 & 2.5 \\
$R \mathrm{p}(\%)$ & 9.7 & 5.4 \\
$R$ wp $(\%)$ & 11.6 & 6.5 \\
$R_{\text {exp }}(\%)$ & 10.9 & 10.9 \\
$\chi^{2}$ & 1.45 & 0.36 \\
No. of reflections & 3645 & 2428 \\
\hline
\end{tabular}

such a symmetry and rather points toward a slight monoclinic distortion. This can be seen on Fig. 1, which presents a comparison of the pattern-matching fits of the X-ray diagram in both symmetries. The very small departure
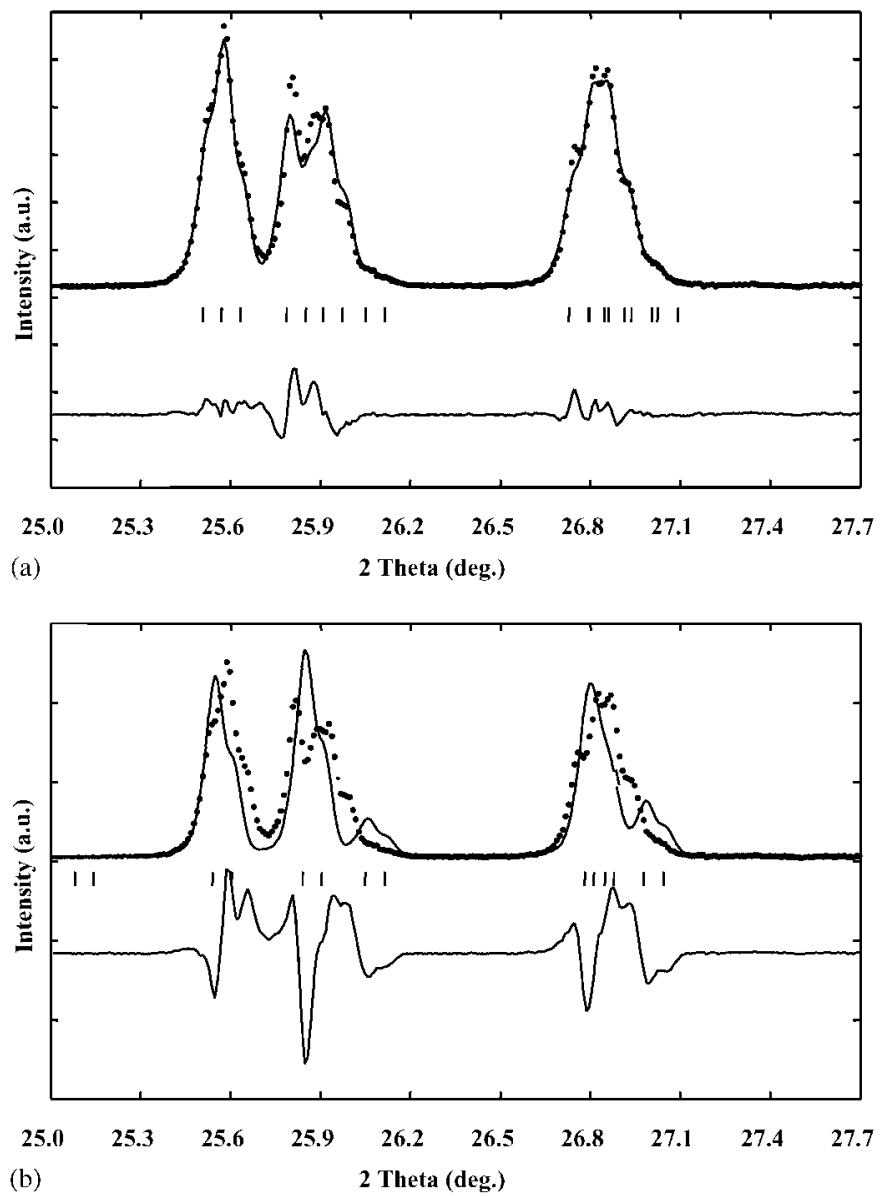

FIG. 1. Details of the pattern-matching fit, for (a) the monoclinic space group $P 2_{1} / n$, and the orthorhombic space group Pmnm (b). Observed (crosses), calculated (line), and difference (lower) patterns are shown. $\left(\sim 0.25^{\circ}\right)$ of the monoclinic angle from $90^{\circ}$ explains that it could not be detected on the electron diffraction patterns. However, the observed reflection conditions (see Fig. 2a), $h 0 l: h+l=2 n$ and $0 k 0: k=2 n$, suggest a monoclinic space group $P 2_{1} / n$ (No. 14). Note that the weak $0 k 0$ reflections with $k=2 n+1$ are observed in the [100] E.D. pattern (Fig. 2b), due to double diffraction effects. The patternmatching fits, computed from the X-ray data within the $2 \theta$ range $\left[5^{\circ}-60^{\circ}\right]$, in the orthorhombic Pmnm (No. 59) and monoclinic $P 22_{1} / n$ (No. 14) space groups, led to reliability factors 36.7 and $18.2 \%$, respectively. This definitively rules out the orthorhombic symmetry.
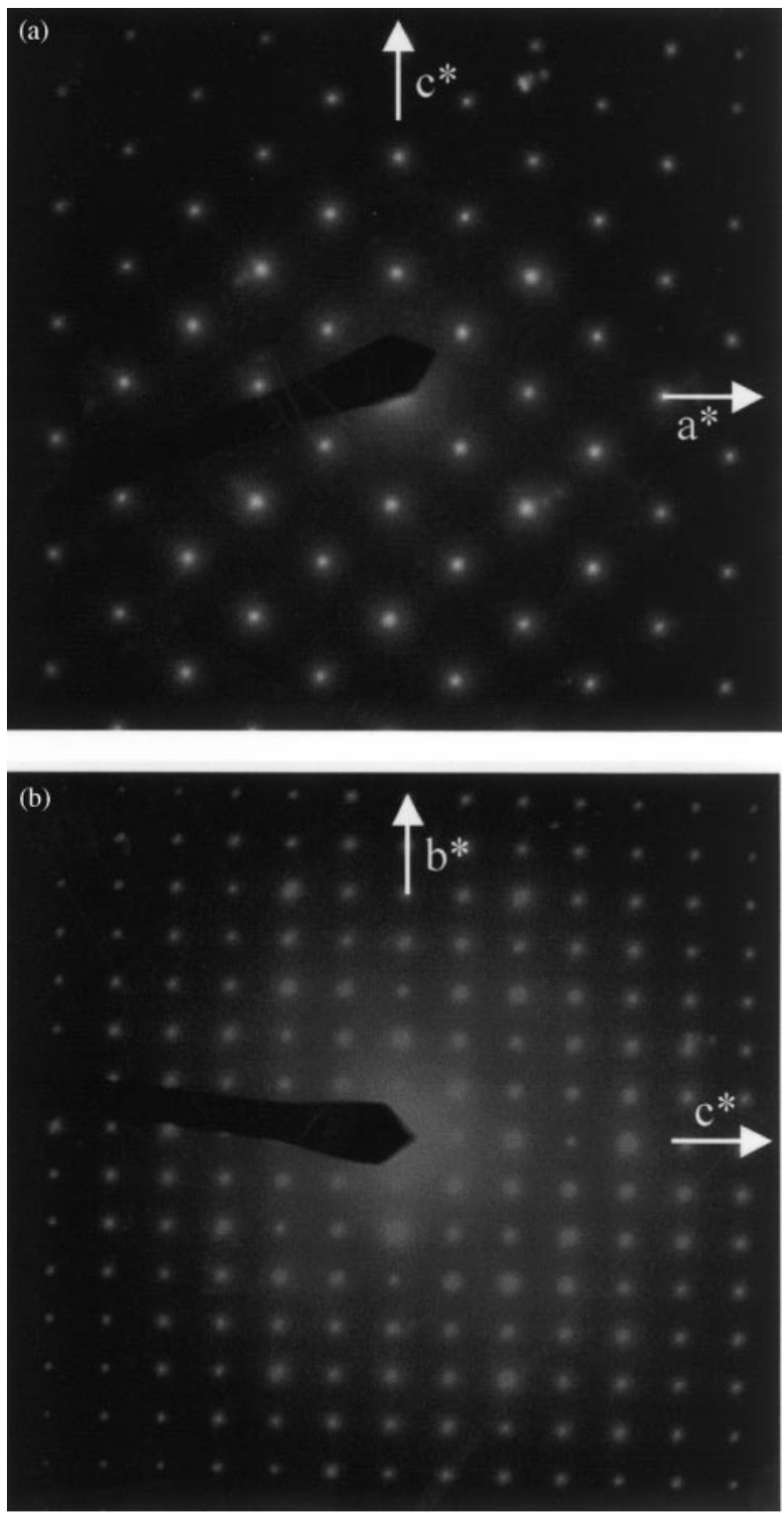

FIG. 2. Electron diffraction pattern of $\mathrm{La}_{2} \mathrm{Mo}_{4} \mathrm{O}_{15}$ along [010]* (a) and $[100]^{*}(\mathrm{~b})$ 


\section{Structural Determination}

The ab initio structural determination was carried out in the monoclinic cell, space group $P 2_{1} / n$. The cell parameters deduced from the electronic diffraction were refined from 16 peak positions in the range $10-25^{\circ}$, with the program UFIT (11). The cell parameters found by this procedure were: $a=9.039(3) \AA, \quad b=12.777(3) \AA, \quad c=10.644(3) \AA$, $\beta=90.24(2)^{\circ}$. Direct methods were applied to the observed intensities, as extracted by the program Fullprof (Profile Matching mode) from the X-ray diffraction pattern. The analysis of positions found by the direct methods (ShelxS86) gave a preliminary solution with four atomic sites attributed to lanthanum and molybdenum in general positions $4 e$ : La1, La2, Mo1, and Mo2. The cation-cation distances obtained from this solution are regular $(\approx 3.6 \AA)$. The rest of the atomic sites were located after subsequent cycles of refinement and Fourier syntheses. At the final stage, all the atomic sites and the isotropic thermal factors of the heavy atoms were refined. Under these conditions the lowest $R_{\text {Bragg }}$ reliability factor is $(8.06 \%)$. In order to get a better precision on the oxygen atoms location and to decrease the number of refined parameters versus the number of observed reflections, a structural refinement was performed using both X-ray and neutron diffraction patterns, with a $50 \%-50 \%$ weighting scheme. The simultaneous X-ray and neutron refinement was carried out using the program Fullprof (8). The final atomic positions and refined patterns are given in Table 2 and Fig. 3, respectively.

\section{Structure Analysis}

La1 and La2 coordination polyhedra are similar in shape, as through a mirror plane (see Fig. 4), but can hardly be described as regular polyhedra. La1 is surrounded by eight oxygen atoms at distances ranging from 2.36 to $2.57 \AA$ and a ninth oxygen atom at $3.03 \AA$, while La2 is surrounded by nine oxygen atoms at distances ranging from 2.41 to $2.70 \AA \AA$ (Table 3 and Fig. 4).

The Mo1 coordination polyhedron is an almost regular tetrahedron formed by four oxygen atoms at distances between 1.73 and $1.82 \AA$. The angles $\mathrm{O}-\mathrm{Mo} 1-\mathrm{O}$ range from $105^{\circ}$ to $111^{\circ}$. The Mo2 coordination polyhedron is also an almost regular tetrahedron with four oxygen atoms at distances ranging from 1.74 to $1.81 \AA$, O-Mo2-O angles are between $106.5^{\circ}$ and $114^{\circ}$. The Mo3 polyhedron could at first sight be described as an almost regular tetrahedron formed by four oxygen atoms at distances from 1.71 to $1.82 \AA$, with $\mathrm{O}-\mathrm{Mo} 3-\mathrm{O}$ angles ranging from $106^{\circ}$ to $116^{\circ}$. In fact, the Mo3 polyhedron has a fifth oxygen neighbor at a much longer distance, $2.53 \AA$. This polyhedron can be described as a distorted trigonal bipyramid. Mo4 is the only molybdenum atom in the structure to adopt a distorted octahedral coordination formed by six oxygen atoms with distances
TABLE 2

Refined Crystallographic Parameters of $\mathrm{La}_{2} \mathrm{Mo}_{4} \mathrm{O}_{15}$ at RT Space Group: $\mathrm{P}_{1} / n$ (No. 14), $Z=4$

\begin{tabular}{|c|c|c|c|c|c|}
\hline Atom & Site & $x$ & $y$ & $z$ & $B_{\text {iso }}\left(\AA^{2}\right)$ \\
\hline La1 & $4 e$ & $0.0874(2)$ & $0.3578(2)$ & $0.7724(2)$ & $0.57(5)$ \\
\hline $\mathrm{La} 2$ & $4 e$ & $-0.3464(2)$ & $0.3728(2)$ & $0.7574(2)$ & $0.62(6)$ \\
\hline Mo1 & $4 e$ & $-0.1365(3)$ & $0.3360(2)$ & $0.0915(3)$ & $0.61(6)$ \\
\hline Mo2 & $4 e$ & $0.3741(3)$ & $0.3446(2)$ & $0.0605(3)$ & $0.54(6)$ \\
\hline Mo3 & $4 e$ & $-0.0747(3)$ & $0.5902(2)$ & $0.6006(3)$ & $0.66(7)$ \\
\hline Mo4 & $4 e$ & $0.3060(3)$ & $0.5597(2)$ & $0.6199(3)$ & $0.65(7)$ \\
\hline $\mathrm{O} 1$ & $4 e$ & $0.378(1)$ & $0.227(1)$ & $0.155(1)$ & $0.8(2)$ \\
\hline $\mathrm{O} 2$ & $4 e$ & $0.890(1)$ & $0.488(1)$ & $0.711(1)$ & $0.6(2)$ \\
\hline $\mathrm{O} 3$ & $4 e$ & $0.884(1)$ & $0.551(1)$ & $0.440(1)$ & $0.8(2)$ \\
\hline O4 & $4 e$ & $0.829(1)$ & $0.453(1)$ & $0.183(1)$ & $1.3(2)$ \\
\hline O5 & $4 e$ & $0.110(1)$ & $0.647(1)$ & $0.607(1)$ & $1.0(2)$ \\
\hline O6 & $4 e$ & $0.875(1)$ & $0.366(1)$ & $-0.075(1)$ & $0.7(2)$ \\
\hline O7 & $4 e$ & $0.807(1)$ & $0.690(1)$ & $0.636(1)$ & $1.2(2)$ \\
\hline O8 & $4 e$ & $0.410(1)$ & $0.663(1)$ & $0.677(1)$ & $1.0(2)$ \\
\hline O9 & $4 e$ & $0.349(1)$ & $0.555(1)$ & $0.460(1)$ & $1.1(2)$ \\
\hline $\mathrm{O} 10$ & $4 e$ & $0.525(1)$ & $0.356(1)$ & $-0.041(1)$ & $1.4(2)$ \\
\hline O11 & $4 e$ & $0.384(1)$ & $0.446(1)$ & $0.691(1)$ & $0.9(2)$ \\
\hline $\mathrm{O} 12$ & $4 e$ & $0.376(1)$ & $0.452(1)$ & $0.160(1)$ & $1.4(2)$ \\
\hline $\mathrm{O} 13$ & $4 e$ & $0.216(1)$ & $0.351(1)$ & $-0.034(1)$ & $1.2(2)$ \\
\hline O14 & $4 e$ & $-0.278(1)$ & $0.247(1)$ & $0.121(1)$ & $1.1(2)$ \\
\hline O15 & $4 e$ & $0.023(1)$ & $0.276(1)$ & $0.147(1)$ & $1.3(2)$ \\
\hline
\end{tabular}

between 1.73 and $2.44 \AA$, O-Mo4-O angles being distributed between $70^{\circ}$ and $107^{\circ}$.

The bond valence calculations were performed using the Brown-Altermatt empirical expression: $\quad$ Valence $=$ $\Sigma \exp \left(R_{0}-d\right) / B$ with $B=0.37 \AA$ (12). We have used for $R_{0}$ the values given in (13), that is $R_{0}=2.172 \AA$ for $\mathrm{La}^{3+}$

TABLE 3

Selected Bond Distances ( $\AA$ ) for $\mathrm{La}_{2} \mathrm{Mo}_{4} \mathrm{O}_{15}$

\begin{tabular}{llll}
\hline La1-O1 & $2.51(1)[\times 1]$ & La2-O1 & $2.64(1)[\times 1]$ \\
La1-O2 & $2.53(1)[\times 1]$ & La2-O2 & $2.64(1)[\times 1]$ \\
La1-O3 & $2.55(1)[\times 1]$ & La2-O6 & $2.68(1)[\times 1]$ \\
La1-O4 & $2.57(1)[\times 1]$ & La2-O7 & $2.62(1)[\times 1]$ \\
La1-O6 & $2.54(1)[\times 1]$ & La2-O9 & $2.49(1)[\times 1]$ \\
La1-O13 & $2.36(1)[\times 1]$ & La2-O10 & $2.45(1)[\times 1]$ \\
La1-O14 & $2.43(1)[\times 1]$ & La2-O11 & $2.70(1)[\times 1]$ \\
La1-O8 & $2.54(1)[\times 1]$ & La2-O12 & $2.41(1)[\times 1]$ \\
La1-O11 & $3.03(1)[\times 1]$ & La2-O15 & $2.52(1)[\times 1]$ \\
Mo1-O4 & $1.81(1)[\times 1]$ & Mo2-O1 & $1.81(1)[\times 1]$ \\
Mo1-O6 & $1.82(1)[\times 1]$ & Mo2-O10 & $1.75(1)[\times 1]$ \\
Mo1-O14 & $1.74(1)[\times 1]$ & Mo2-O12 & $1.74(1)[\times 1]$ \\
Mo1-O15 & $1.73(1)[\times 1]$ & Mo2-O13 & $1.74(1)[\times 1]$ \\
Mo3-O2 & $1.78(1)[\times 1]$ & Mo4-O8 & $1.73(1)[\times 1]$ \\
Mo3-O3 & $1.82(1)[\times 1]$ & Mo4-O9 & $1.75(1)[\times 1]$ \\
Mo3-O5 & $1.82(1)[\times 1]$ & Mo4-O11 & $1.78(1)[\times 1]$ \\
Mo3-O7 & $1.71(1)[\times 1]$ & Mo4-O3 & $2.31(1)[\times 1]$ \\
Mo3-O3 & $2.53(1)[\times 1]$ & Mo4-O4 & $2.44(1)[\times 1]$ \\
& & Mo4-O5 & $2.09(1)[\times 1]$ \\
\hline
\end{tabular}



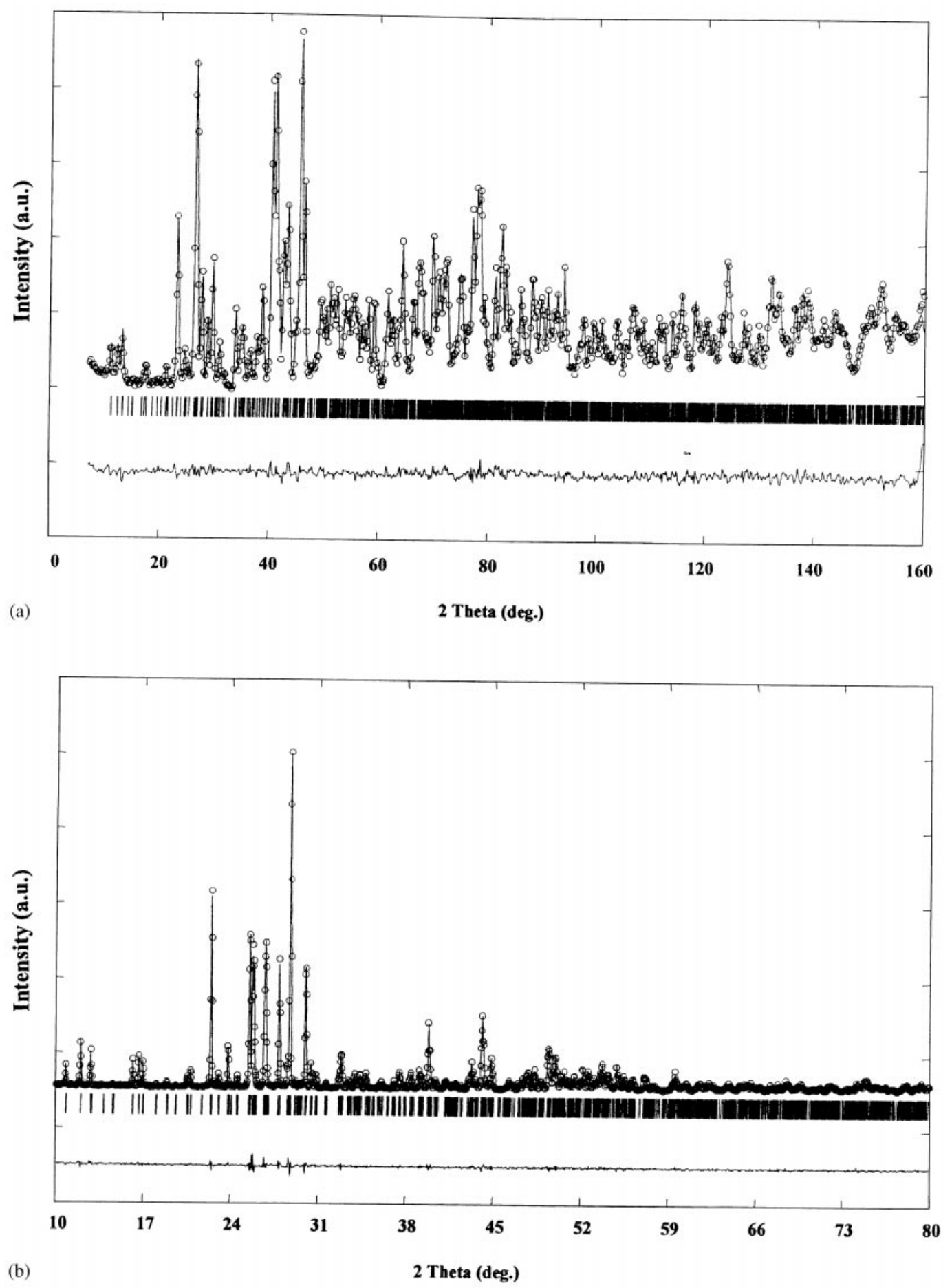

FIG. 3. Final profil refinement of $\mathrm{La}_{2} \mathrm{Mo}_{4} \mathrm{O}_{15}$ for (a) the neutron pattern and (b) the X-ray pattern. Observed (crosses), calculated (line), and difference (lower) patterns are shown.

and $R_{0}=1.907 \AA$ for $\mathrm{Mo}^{6+}$. The valence calculations for the lanthanum atoms give 3.44(4) and 3.17(4) for La1 and La2, respectively, slightly in excess of the expected +3 . For the molybdenum atoms the valence calculations give 5.75(6),
5.97(6), 5.83(6), and 5.74(6) for Mo1, Mo2, Mo3, and Mo4, respectively, slightly lower than the expected +6 .

The coordination polyhedra of the different cations present some interesting features, some of them sharing one or 


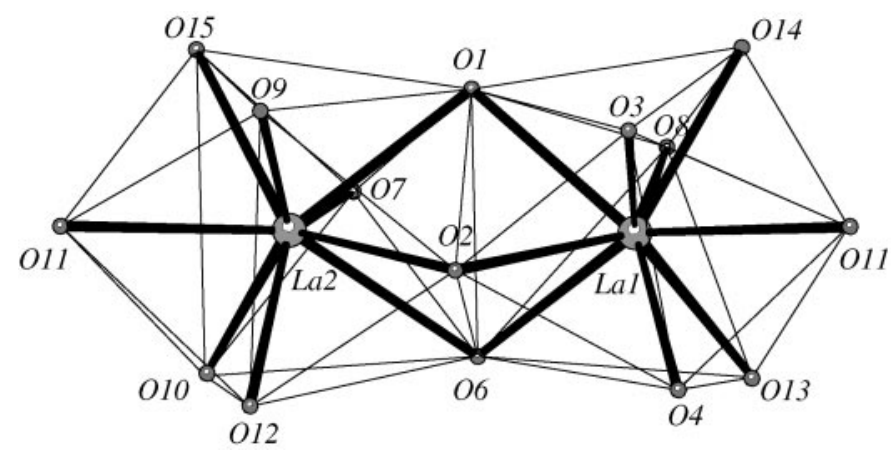

FIG. 4. Coordination polyhedra of La1 and La2 connected together by a face formed by $\mathrm{O} 1, \mathrm{O} 2$, and $\mathrm{O} 6$ and by a vertex $\mathrm{O} 11$.

several oxygen atoms. The lanthanum coordination polyhedra are connected together alternatively by a face formed by oxygen atoms $\mathrm{O} 1, \mathrm{O} 2$, and $\mathrm{O} 6$ and by a vertex $\mathrm{O} 11$ (Fig. 4). They are thus forming infinite chains of formula
$\left[\mathrm{La}_{2} \mathrm{O}_{14}\right]_{\infty}$ running along a (see Fig. 5a). The molybdenum coordination polyhedra build up a large unit of formula $\left[\mathrm{Mo}_{6} \mathrm{O}_{22}\right]$ formed by four tetrahedra (Mo3 and Mo1) and two octahedra (Mo4) (Fig. 6a). The structure of $\mathrm{La}_{2} \mathrm{Mo}_{4} \mathrm{O}_{15}$ can be described by $\left[\mathrm{Mo}_{6} \mathrm{O}_{22}\right]$ units and twice as many $\left[\mathrm{MoO}_{4}\right]$ isolated tetrahedra (Mo2), surrounding lanthanum files (Fig. 5). These units of tetrahedra and octahedra sharing vertices are not unusal in molybdenum oxides; for instance $\mathrm{Na}_{2} \mathrm{Mo}_{2} \mathrm{O}_{7}$ and $\mathrm{K}_{2} \mathrm{Mo}_{3} \mathrm{O}_{10}$ are given by A. F. Wells as displaying the same type of units (14). In the case of other known lanthanide molybdates $L n_{2} \mathrm{Mo}_{4} \mathrm{O}_{15}$, one can point out the structures of $\mathrm{Ho}_{2} \mathrm{Mo}_{4} \mathrm{O}_{15}$ (15) and $\mathrm{Ce}_{2} \mathrm{Mo}_{4} \mathrm{O}_{15}$ (16). The structure of the holmium molybdate $\mathrm{Ho}_{2} \mathrm{Mo}_{4} \mathrm{O}_{15}$ is built up from $\left[\mathrm{Mo}_{4} \mathrm{O}_{15}\right]$ units which are formed by two bipyramids of formula $\mathrm{MoO}_{5}$ and two tetrahedra which share their vertices (Fig. 6b). The structure of $\mathrm{Ce}_{2} \mathrm{Mo}_{4} \mathrm{O}_{15}$ can be described from infinite chains of formula $\left[\mathrm{Mo}_{4} \mathrm{O}_{14}\right]_{\infty}$ and isolated $\left[\mathrm{MoO}_{4}\right]$ tetrahedra (Fig. 6c). These infinite chains consist of edge-sharing pairs of $\left[\mathrm{MoO}_{6}\right]$ octahedra bridged by two tetrahedra.

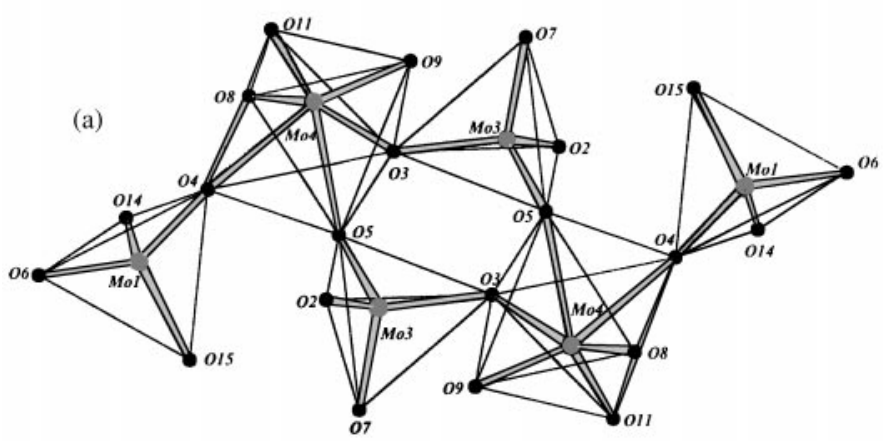

(b)
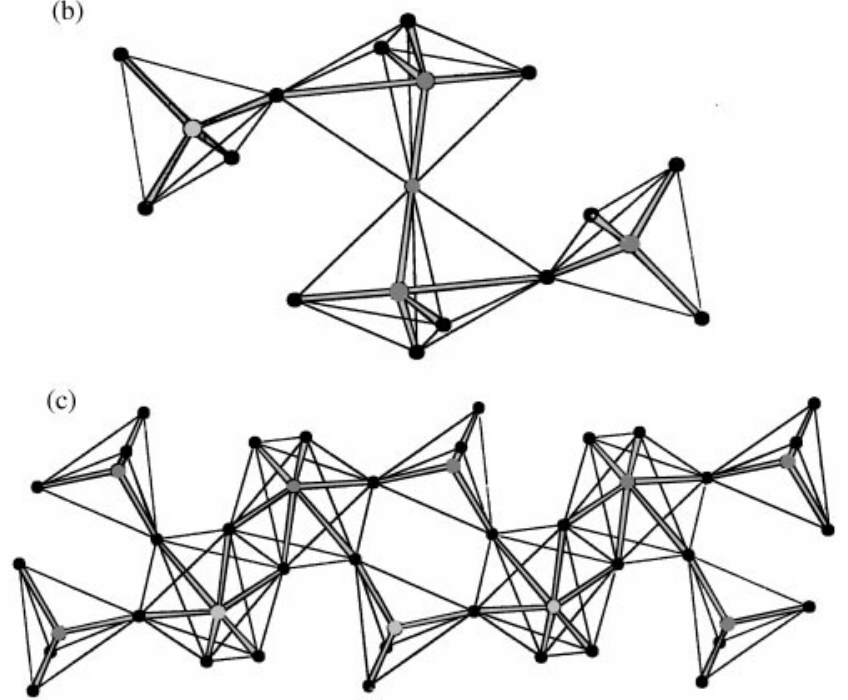

FIG. 6. Different molybdenum coordination polyhedra units observed in (a) $\mathrm{La}_{2} \mathrm{Mo}_{4} \mathrm{O}_{15}$, (b) $\mathrm{Ho}_{2} \mathrm{Mo}_{4} \mathrm{O}_{15}$, and (c) $\mathrm{Ce}_{2} \mathrm{Mo}_{4} \mathrm{O}_{15}$.
FIG. 5. Details of the $\mathrm{La}_{2} \mathrm{Mo}_{4} \mathrm{O}_{15}$ structure in terms of polyhedra: (a) a $\left[\mathrm{La}_{2} \mathrm{O}_{14}\right]_{\infty}$ chain with its surroundings of molybdenum polyhedra; (b) $\mathrm{a}\left[\mathrm{Mo}_{6} \mathrm{O}_{22}\right]$ unit with its surroundings of $\left[\mathrm{La}_{2} \mathrm{O}_{14}\right]_{\infty}$ chains (for clarity, two of them are open) hatched, and La polyhedra are grayed (darker gray), as well as isolated Mo tetrahedra (light gray). The polyhedra of $\left[\mathrm{Mo}_{6} \mathrm{O}_{22}\right]$ units are hatched. 


\section{CONCLUSION}

We have investigated the complex structure of $\mathrm{La}_{2} \mathrm{Mo}_{4} \mathrm{O}_{15}$ by means of a coupled refinement of X-ray and neutron powder diffraction pattern. The coupled refinement has permitted to increase the number of data in order to refine the 84 structural parameters. The structure of $\mathrm{La}_{2} \mathrm{Mo}_{4} \mathrm{O}_{15}$ is built up from $\left[\mathrm{Mo}_{6} \mathrm{O}_{22}\right]$ units formed by molybdenum octahedra $\left[\mathrm{MoO}_{6}\right]$ and tetrahedra $\left[\mathrm{MoO}_{4}\right]$. These complex units are often present in molybdates, and the comparison of the structures of $\mathrm{Ln}_{2} \mathrm{Mo}_{4} \mathrm{O}_{15}(\mathrm{Ln}=\mathrm{La}$, $\mathrm{Ce}, \mathrm{Ho}$ ) shows a diversity of molybdate units: $\left[\mathrm{Mo}_{6} \mathrm{O}_{22}\right]$, $\left[\mathrm{Mo}_{4} \mathrm{O}_{14}\right]_{\infty},\left[\mathrm{Mo}_{4} \mathrm{O}_{15}\right]$ for $\mathrm{La}, \mathrm{Ce}$, and $\mathrm{Ho}$, respectively. The structural and transport properties of $\mathrm{La}_{2} \mathrm{Mo}_{4} \mathrm{O}_{15}$ have been explored. The compound shows a regular thermal expansion with no phase transition up to decomposition, and it does not exhibit any oxide-ion conduction property.

\section{REFERENCES}

1. W. Jeitschko, Acta Crystallogr. B 28, 60 (1972).

2. J. S. O. Evans, T. A. Marry, and A. W. Sleight, J. Solid State Chem. 133, 580 (1997).

3. J. S. Xue, M. R. Antonio, and L. Soderholm, Chem. Mater. 7, 333-340 (1995).
4. P. Lacorre, F. Goutenoire, O. Bohnke, R. Retoux, and Y. Laligant, Nature 404, 856-858 (2000).

5. F. Goutenoire, O. Isnard, R. Retoux, and P. Lacorre, Chem. Mater. 12(9), 2575-2580 (2000).

6. F. Goutenoire, O. Isnard, E. Suard, O. Bohnke, Y. Laligant, R. Retoux, and Ph. Lacorre, J. Chem. Mater. 11(1), 119-124 (2001).

7. F. P. Alekseev, E. I. Get'man, G. G. Koshcheev, and M. V. Mokhosoev, Russ. J. Inorg. Chem. 14, 1558 (1969).

8. J. Rodriguez-Carvajal, in "Collected Abstracts of Powder Diffraction Meeting, Toulouse, France, 1990,” p. 127.

9. G. M. Sheldrick, ShelxS86, in "Crystallographic Computing 3" (G. M. Sheldrick, C. Krüger, and R. Goddard, Eds.), Oxford Univ. Press, Oxford, 1985; G. M. Sheldrick, "ShelxL93: A Program for Refinement of Crystal Structures from Diffraction Data." Univ. of Göttingen, Germany, 1993.

10. P. E. Werner, L. Eriksson, and M. Westdhal, J. Appl. Crystallorgr. 18, 367 (1985).

11. M. Evain, "UFIT program V1.3.” Institut des Matériaux de Nantes, Nantes, France, 1992.

12. I. D. Brown and D. Altermatt, Acta Crystallogr. B 41, 244 (1985).

13. N. E. Brese and M. O'Keeffe, Acta Crystallogr. B 47, 192 (1991).

14. A. F. Wells, "Structural Inorganic Chemistry," 3rd ed., Chap. 10, p. 446. Oxford at the Clarendon Press, 1962.

15. V. A. Efremov, N. N. Dvydova, L. Z. Gokham, A. A. Evdokimov, and V. K. Trunov, Russ. J. Inorg. Chem. 33, 12 (1988).

16. G. D. Gallon and B. M. Gathehouse, J. Solid State Chem. 44, 156-161 (1982). 